\title{
IMPLEMENTASI MAKERSPACE DI PERPUSTAKAAN KOTA YOGYAKARTA
}

\author{
Annisa Rohmawati*
}

Pengutipan: Annisa Rohmawati, (2016). Implementasi Makerspace di Perpustakaan Kota Yogyakarta. Khizanah Al-Hikmah Jurnal Ilmu Perpustakaan, Informasi, dan Kearsipan, 4(2), 163-167.

*Pustakawan di Kantor Arsip dan Perpustakaan Daerah Kota Yogyakarta (annisarohmawati@gmail.com)

\begin{abstract}
ABSTRAK
Artikel ini menyajikan mengenai suatu karya yang dihasilkan oleh suatu masyarakat, yang bertujuan untuk melatih ketrampilan dan menambah kekreatifan. Makerspace adalah salah satu kegiatan seseorang atau kelompok dalam menghasilkan suatu karya. Karya yang diciptakan dapat berupa karya baru atau recycle bahan yang telah tersedia. Perpustakaan Kota Yogyakarta salah satu perpustakaan yang telah memanfaatkan makerspace sebagai kegiatan rutin dalam mengisi liburan anak-anak. Di sana diajarkan bagaimana membuat barang-barang unik yang terbuat dari bahan tidak terpakai dan juga membuat lukisan yang dibuat bersamasama. Antusias dari anak-anak sangat tinggi, mereka sangat senang dan menikmati kegiatan. Untuk itu perlunya kegiatan makerspace di perpustakaan untuk menambah pengetahuan dan mengasah ketrampilan bagi anak-anak. Sekaligus penting untuk menambah daya tarik anak untuk datang ke perpustakaan.
\end{abstract}

Kata Kunci: Perpustakaan Umum, Makerspace

\section{ABSTRACT}

This article presents about a work produced by a society, which aims to train skills and add creativity. Makerspace is one person's or group's activities in producing a work. Works created new works or can be either recycle materials you have available. Works created new works or can be either recycle materials you have available. The city library is one of the libraries that have leveraged makerspace as regular activity in filling the holiday for children. There were taught how to make unique items made of unused materials and also made paintings that were created together. Enthusiasm of children is very high, they are very happy and enjoy the activities. To that end the need for activities in the library to add makerspace knowledge and hone skills for children. At the same time it is important to add to the attractiveness of the child to come to the library.

Key words: Public Library, MakerSpace

\section{PENDAHULUAN}

Karya seni yang diciptakan adalah sebuah karya yang patut dihargai. Dilihat dari segi arti, karya memiliki identitas tersendiri. Hasil karya cipta manusia ber- dasarkan keterampilan yang dimiliki. Tidak semua orang memiliki keterampilan yang sama persis. Memiliki kelebihan dalam menciptakan sesuatu dapat menjadi hobi, dikerjakan dengan senag hati sesui keinginan. Kesamaan hobi antara satu orang dengan lainnya 


\section{Bloom Taxonomy of Learning}

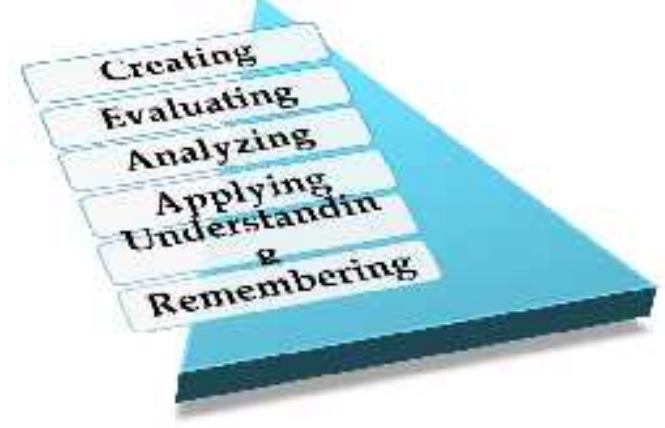

Tahap-tahap pemahaman dalam pembuatan suatu produk. Langkah pertama menentukan apa yang akan dibuat, kemudian mengevaluasi apakah produk/karya tersebut dapat digunakan atau hanya sebagai pajangan saja. Di analisis menurut fungsi dan tujuannya. Diterapkan dalan kehidupan sehari-hari, apakah bermasalah atau tidak. Setelah itu, dipahami. Memahami penggunaan yang baik dan benar, sesuai dengan yang diinginkan atau tidak. Terakhir mengingat. Dengan melakukan pembuatan produk kita jadi mengingatingat apa yang kita buat. Dapat mengeksplorasi lebih jauh bahka membuatnya lebih baik lagi.

\section{b. Makerspace di Indonesia}

Makerspace Indonesia memiliki komunitas seperti halnya di negara maju lainnya. Mereka mengeluarkan ide-ide kreatif dan melakukannya bersama-sama di suatu tempat. Ide kreatif dapat berupa produk baru atau mengembangkan dari produk yang pernah ada. Ada beberapa contoh komunitas makerspace di Indonesia antara lain:

1) MakeDoNia yang beralamatkan makedonia.co

2) Crazy Hackerz (Crackerz) yang beralamatkan crazyhackerz.com
3) LifePatch yang beralamatkan lifepatch.org

4) GeekNesia yang beralamatkan geeknesia.com

5) Gerai Cerdas yang beralamatkan geraicerdas.com

6) Bekasi Makerspace (sedang dalam proses pengembangan)

7) Indoestri yang beralamatkan indoestri.com

Dari sekian daftar komunitas makerspace memiliki jenis kegiatan yang berbeda-beda. Mereka menyebar di seluruh indonesia. Jika kita lihat secara umum komunitas ini mungkin masih asing di telinga kita. Karena memang belum semua daerah mengenal bahkan mengetahui adanya makerspace.

Menarik jika kita mengetahui, mengulas, mengenal makerspace ini. Banyak manfaat positif yang didapat. Selain bertambahnya pengetahuan, dapat pula menambah ide kreatif dalam diri kita.

\section{c. Makerspace di Perpustakaan Kota Yogyakarta.}

Kegiatan yang ada di Perpustakaan Kota Yogyakarta cukup menarik. Perpustakaan Kota atau yang lebih akrab di sebut Perpuskota ini, mengadakan kegiatan liburan di Perpuskota dan sanggar menulis cahaya. Kedua kegiatan tersebut rutin dilaksanakan di Perpuskota. Sanggar menulis cahaya (SMC) adalah kegiatan yang mengajarkan anak-anak untuk menulis, mengeksplorasikan diri membuka ruang ilmu yang lebih luas. Mereka membuat sebuah cerita dapat berlatarbelakang dari kehidupan seharihari. Kumpulan cerita kemudian di cetak dan dijadikan buku. 


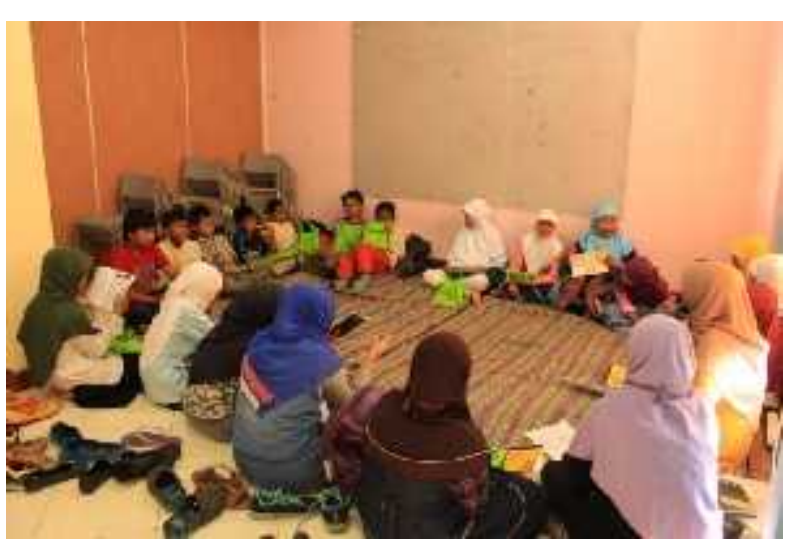

Sumber: Pertemuan rutin SMC (dokmentasi pribadi)

Kegiatan kedua adalah Liburan di PerpusKota. Sasaran kegiatannya adalah anak-anak sekolah sampai dengan usia 12 th. Mereka diberikan kegiatan yang menarik. Salah satunya membuat mural, anak-anak diberikan kebebasan untuk membuat apapun yang diinginkan sesuai tema. Membuat desain tas, membuat buku.

Tujuan diselenggarakannya acara ini adalah untuk melatih keberanian, kreatifitas, dan pengalaman. Acara ini diselenggarakan ketika libur anak sekolah jadi untuk mengisi waktu luang diisi dengan kegiatan yang bersifat edukatif dan rekreatif.

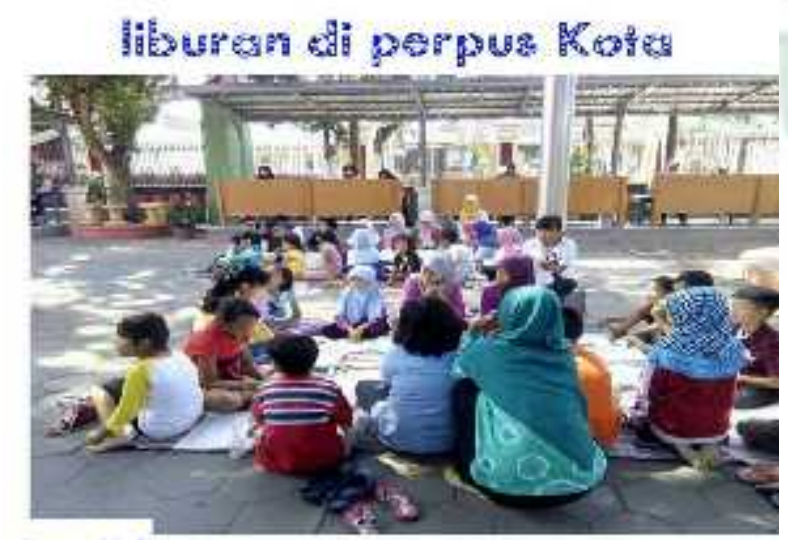

day \#1

Seluruh kegiatan tersebut disebut juga dengan makerspace. Bertempat di Perpustakaan Kota Yogyakarta yang mana kegiatan tersebut menghasilkan suatu produk, suatu karya yang bermanfaat. Harapannya, anak-anak dapat mengembangkan kreatifitasannya, mengembangkan interaksi dengan sesama, meningkatkan imajinasi dan daya kreasi anak.

\section{PENUTUP}

\section{a. Kesimpulan}

Dari pembahasan diatas dapat diambil kesimpulan bahwa, segala kegiatan yang menghasilkan karya yang bermanfaat bagi diri sendiri maupun orang lain disebut juga dengan Makerspace. Banyak komunitas telah tersebar di Indonesia. Mereka menyediakan sebuah tempat untuk belajar bersama dengan berbagai macam kegiatan.

Kegiatan yang diselenggarakan di Perpustakaan Kota Yogyakarta, berbasis kemasyarakatan.

Perpuskota menginginkan masyarakat lebih sadar dalam mengolah sesuatu/bahan yang biasa menjadi bahan yang lebih berguna. Meningkatkan kreatifitas, mengajarkan arti kemandirian dan kebersamaan. Harapannya masyarakat menjadi lebih terbuka dan memahami pentingnya berbagi pengalaman.

\section{b. Saran}

Sebagai seorang pustakawan, kita harus lebih kreatif, inovatif dalam mengadakan kegiatan. Karena perkembangan masyarakat yang lebih kritis dalam berpikir, pustakawan juga harus lebih kritis dalam menanggapinya. Perpustakaan harus jadi pelopor makerspace untuk kemajuan masyarakat yang lebih cerdas. 


\section{DAFTAR PUSTAKA}

Taufiqqurakhman, Ahmad, MakerSpace, Jejaring Sosial Bagi Insan Kreatif dalam

http://teknologi.inilah.com/read/d etail/2200620/makerspace-jejaringsosial-bagi-insan-kreatif. Diakses pada 13 Juni 2016, pukul 14:05 WIB.

http://searchmanufacturingerp.techtarget .com/definition/Makerspace

http://www.ucdenver.edu/faculty_staff/ faculty/center-for-facultydevelopment/Documents/Tutorials /Assessment/module2/index.htm

Putra, Adhitya Wibawa, Makerspace, Tempat Kolaborasi Para Maker Untuk Menciptakan Produk, dalam teknojurnal.com/makerspace. Diakses pada 13 Juni 2016, pukul 17:05 WIB. 